\title{
Na drodze do dyktatury. Polityka i propaganda Republiki Weimarskiej w prasie niemieckiej i polskiej w Niemczech do roku 1933
}

Dyktaturę rozumie się zwykle w kontekście pojęcia ideologii pojmowanej jako oś światopoglądowa polityki1. W dziele Totalitarian Dictatorship and Autocracy z roku 1956 Carl Joachim Friedrich i Zbigniew Brzeziński ${ }^{2}$ zdefiniowali kilka fundamentalnych cech systemów totalitarnych - przede wszystkim działanie według zasad sformułowanej i dookreślonej teoretycznie ideologii, często o charakterze utopii noszącej cechy pseudoreligii, sprawowanie rządów przez monopolizującą władzę, oligarchicznie zorganizowaną partię polityczną o charakterze wodzowskim ugruntowaną $\mathrm{w}$ aparacie biurokratycznym, stosowanie przez państwo w takim systemie fizycznego i psychicznego terroru wobec obywateli przy pomocy aparatu przymusu ${ }^{3}$. W modelu tym istnieje wyraźny monopol państwa na środki masowej komunikacji ${ }^{4}$. Peter Graf Kielmansegg w dziele Die Grammatik der Freiheit. Acht Versuche über den demokratischen Verfassungsstaat ${ }^{5}$ krytykował model Friedricha/Brzezińskiego, uzupełniając go o element dynamiki rozwoju społecznego. Cechą charakterystyczną jest koncentracja władzy w jednym ośrodku decyzyjnym ${ }^{6}$.

\footnotetext{
* Prof. dr hab., e-mail: mostrowski54@wp.pl; Uniwersytet Łódzki, Katedra Dziennikarstwa i Komunikacji Społecznej.

${ }^{1}$ Niektórzy autorzy są zdania, że systemy totalitarne są ideokracjami - ideocracies. Tak czyni np. Juan J. Linz w swym dziele Totalitäre und autoritäre Regime, Potsdamer Textbücher, Bd 4, WeltTrends e.V., Potsdam 2009, a także: Manuel Becker w Ideologiegeleitete Dikaturen in Deutschland, Forum Junge Politikwissenschaft, Band 18, BouvierVerl. Bonn 2009, rozdział: Ideologia obydwu niemieckich dyktatur (Die Ideologie der beiden deutschen Diktaturen), s. 64-145.

${ }^{2}$ C.J Friedrich, Z. Brzeziński, Totalitarianism dictatorship and autocracy, Harvard University Press, Cambridge 1956.

${ }^{3}$ Należy do niego wojsko i policja gotowe do użycia przeciwko własnym obywatelom.

${ }^{4}$ Służą one rzeczywistemu i skutecznemu osiąganiu totalnej kontroli. W odróżnieniu od samego jedynie dążenia do totalitarnej kontroli.

${ }^{5}$ P.G. Kielmansegg, Die Grammatik der Freiheit. Acht Versuche über den demokratischen Verfassungsstaat, Nomos Verlagsgesellschaft, Baden-Baden 2013.

${ }^{6}$ Osobnym zagadnieniem jest przy tym legitymizacja władzy. $Z$ historycznej perspektyw prawidłowym ujęciem zasady legitymizacji byłoby na przykład stanowisko Maxa Webera, który pisze
} 
Utożsamia on system państwowy z systemem prawnym, tak jak to czynią Carl Schmitt czy Eric Voegelin? - jako konieczność interpretacji wszelkich kodeksów prawnych z punktu widzenia możliwości realizacji kompletu sankcji w nich przewidzianych. Terror dotyczy w tym systemie również ograniczenia możliwości komunikacji ${ }^{8}$. Istotę totalitaryzmu najpełniej chyba określa Hannah Arendt w znanym powszechnie dziele wydanym w roku 1951 - The Origins of Totalitarianism. Znaczenie terroru w systemie totalitarnym jest fundamentalne: „Polityczne kontakty między ludźmi są przy rządach tyrańskich przerwane, cechujące zaś ludzi umiejętności działania i rządzenia okazują się bezsilne.(...) Przymus totalitarnej logiki niszczy zdolność człowieka do przeżywania i myślenia, tak samo, jak jego zdolność do działania." ${ }^{9}$ Cechy władzy totalitarnej według Arendt to:

- wola panowania nad światem;

- fanatyzm ruchu masowego oparty o zasadę wodzostwa;

- możliwość mordu w imię nowego prawdziwego porządku, co oznacza reinterpretację i zmanipulowanie zasad moralności;

- wiara w „słuszną” ideologię i jej połączenie z propagandą.

Swe rozważania Arendt odnosi głównie do faszyzmu i bolszewizmu. Inne formy władzy tego typu występujące w dziejach nazywa systemami tyranii. Postsowieckie kraje wpływu określa jako nietotalitarne dyktatury ${ }^{10}$.

System mediów w republice weimarskiej był wyraźnie podporządkowany procesowi politycznemu ${ }^{11}$. Istotną jego rolą było wspieranie stronnictw politycz-

o możliwościach legitymizacji władzy w formie środków tradycyjnych, charyzmatycznych i racjonalnych. Systemów autorytarnych nie dotyczy legitymizacja racjonalna. Zob. tenże, Gospodarka i społeczeństwo. Zarys socjologii rozumiejącej, Wydawnictwo Naukowe PWN, Warszawa 2002.

${ }^{7} \mathrm{Carl}$ Schmitt wprowadził do nauk prawnych i politycznych termin decyzjonizm. Zakłada on uznanie wyższości decyzji nad normą prawną w sytuacji dla państwa wyjątkowej - por. C. Schmitt, O trzech sposobach myślenia w nauce prawa, [w:] P. Bała, A. Wielomski, Carl Schmitt a Konstytucja Rzeczpospolitej polskiej. Studium przypadku ratyfikacji Traktatu Lizbońskiego - rola prezydenta RP, Klub Zachowawczo-Monarchistyczny, Warszawa 2008, s. 5. Podobnie utożsamia system prawny i państwowy Eric Voegelin - autor książki Der autoritäre Staat. Ein Versuch über das österreichische Staatsproblem (1936).

${ }^{8}$ Ograniczeniom podlega możliwość kształcenia czy wykonywania zawodu.

${ }^{9}$ H. Arendt, Korzenie totalitaryzmu, Wydawnictwa Akademickie i Profesjonalne, Wyd. IV, Warszawa, s. 664.

${ }^{10}$ Elemente und Ursprünge totaler Herrschaft. Antisemitismus, Imperialismus, Totale Herrschaft, Piper, München 2008. Wydanie polskie: H. Arendt, Korzenie totalitaryzmu, Wydawnictwo Akademickie i Profesjonalne, Warszawa 2008. Według Franza Neumanna rozróżnić można trzy typy dyktatury: klasyczną, cezarejską i totalną; F. Neumann, Notizen zur Theorie der Diktatur, [in:] Demokratischer und Autoritärer Staat. Studien zur politischen Theorie, Frankfurt/M 1967, s. 224-247.

${ }^{11}$ Można pokusić się o stwierdzenie, iż system ten w znacznym stopniu odzwierciedla paralelizm partyjno-medialny jako funkcjonowanie np. prasy czy radia w interesie określonej partii politycznej - por. np. Colin Seymour-Ure w książce The political Impact of Mass Media, Constable, London 1974. Trudno nazwać republikę weimarską dyktaturą, ale z upływem lat mnożą się głosy w mediach optujące za narodowym rządem silnej ręki. Widać przy tym jak na dłoni, że wielką rolę odgrywała w świadomości niemieckiej tamtego okresu „hańba” traktatu wersalskiego. 
nych i występowanie w ich imieniu. Wydaje się, iż rządy republiki, a zwłaszcza gabinet Franza von Papena, znajdowały się na prostej drodze do dyktatury. Dziennikarz polityczny w dobie republiki weimarskiej w swej działalności publicystycznej kształtował opinię publiczną w imieniu określonej frakcji politycznej, reprezentując jej interesy. Zarysowywała się w związku z tym określona panorama czasopism, których związek z polityką staje się oczywisty. Dzieliły się one wyraźnie politycznie, a ich podległość interesom partii stała się racją istnienia. Alfred Wysocki jako poseł RP w Berlinie, w swych sprawozdaniach skierowanych do Ministerstwa Spraw Zagranicznych w Warszawie na ręce ministra Augusta Zalewskiego, a po roku 1933 Józefa Becka - sprawnie i poglądowo dzieli prasę republiki weimarskiej według reprezentowanych opcji politycznych na:

- dzienniki liberalne: „Berliner Börsen-Courier”, „Berliner Tageblatt”, „VossischeZeitung”;

- reprezentujące opcję socjalistyczną: centrowa i narodowosocjalistyczna „Germania”, centrowa „Vorwärts”, narodowosocjalistyczna „Völkischer Beobachter”;

- działające w medialnym interesie Chrześcijańskich Związków Zawodowych „Der Deutsche”;

- niemiecko-narodowe: zbliżona do rządu von Papena „Deutsche Allgemeine Zeitung”, „Kreuzzeitung”, „Der Ring”;

- konserwatywno-narodowe: „Tägliche Rundschau” (gazeta orientująca się politycznie według partii Deutsche Nationale Volkspartei) i inne.

Można pokusić się o stwierdzenie, iż propaganda republiki weimarskiej skierowana była przede wszystkim przeciwko traktatowi wersalskiemu i jego konsekwencjom. Poszczególne rządy po roku 1918 próbowały zająć się ratowaniem niemieckiej tożsamości, zapobiegać powstawaniu „światopoglądu klęski” po zakończeniu pierwszej wojny światowej, szukając w swej polityce przede wszystkim możliwości wyjścia z kryzysu gospodarczego, a w sensie narodowym odgrodzenia się od dominacji Anglii i Francji ${ }^{12}$. Szczególnie ciekawa w tym kontekście jest problematyka polska.

Nasz kraj jest postrzegany przez Niemcy jako narzędzie w rękach mocarstw - głównie Wielkiej Brytanii i Francji - dla zbudowania ich wpływów na wschodzie Europy. Liczne są zatem głosy w czasopismach, iż angielską i francuska politykę uprawia się w Warszawie, by wywrzeć wpływ także na kraje graniczące z Rosją - Litwę, Łotwę, Estonię ${ }^{13}$.

12 Odbywały się przeciwko traktatowi wersalskiemu także publiczne protesty i demonstracje, m.in. wiec protestacyjny 28 czerwca 1932 roku na placu Lustgarten w Berlinie, zorganizowany przez związek studencki Deutsche Studentenschaft (także inne związki studenckie, jak: Jungdeutsche i Grenzbund der buendischen Jugend).

${ }^{13}$ Jako przykład posłużyć może tekst, który Konsulat RP przesłał do MSZ w roku 1927. Jest to wycinek z gazety „Hamburger Fremdenblatt” nr 353 z 22 grudnia 1927 roku. Artykuł nosi tytuł Was will der Polenbund (Czego chce Związek Polaków): „England bildeeinevereinigte Front Europasgegen 
Niemiecka prasa prawicowa starała się dyskredytować Polskę. Miało to miejsce szczególnie w relacjach dotyczących problemów ówczesnego Śląska, Gdańska czy tzw. „korytarza”. Często tematem były niepomyślne objawy życia gospodarczego. Szczególnie „Schlesische Volkszeitung” uprawiała tego rodzaju publicystykę. W kontekście kryzysu gospodarczego w Polsce pisała np. o rosnącej w naszym kraju liczbie protestów wekslowych ${ }^{14}$. Śląskie koła gospodarcze próbowały wpłynąć na rząd niemiecki w celu zawarcia traktatów handlowych z Polską, a przeciwnicy porozumienia dążyli do wybrnięcia z kryzysu drogą uzyskania niemieckich subwencji rządowych. Tę drugą opcję promowały zwłaszcza koła agrarne, ale także przemysłowo-handlowe, zainteresowane rozbudową sieci komunikacyjnej na Śląsku i uwzględnieniem Śląska na szczególnych prawach w polityce taryfowej i celnej. Raport wspomina o wystąpieniach zainteresowanych przedsiębiorców do rządu berlińskiego. I tak koła agrarne wysłały delegację do pruskiego ministra Heinricha Steigera ${ }^{15}$, która miała mu przedstawić postulaty rolnictwa śląskiego $\mathrm{W}$ związku z programem Landbundu. W opozycji do „Schlesische Volkszeitung” znajduje się socjalistyczna gazeta „Volkswacht”. Jest ona szczególnie aktywna w walce politycznej przeciwko Centrum o głosy robotników w wyborach na Dolnym i Górnym Śląsku' ${ }^{16}$. Jako ważny ośrodek badań nad wpływami niemieckimi na wschodzie powstał Osteuropa-Institut Breslau ${ }^{17}$.

Sowjetrußland. Und heute steht bereits fest, daß die englische Politik nicht allein in Warschau, sondern auch in Kowno, Riga und Reval mit außerordentlichem Erfolg gearbeitet hat” („Anglia tworzy zjednoczony front w Europie przeciwko Rosji Sowieckiej. A dziś staje się oczywiste, że angielska polityka uprawiana jest nie tylko w Warszawie, ale także w Kownie, Rydze i Revalu" [tłumaczenie własne]), s. 2. W sprawozdaniu konsula Poselstwa Polskiego do MSZ w Warszawie w roku 1928 czytamy: „Orędzie estońskiego prezydenta z okazji 10-lecia niepodległości Estonii dało prasie niemieckiej powód do zdenerwowania i wystąpienia pod adresem Polski”. „Schlesische Zeitung” z 26 lutego 1928 roku, nr 105, pisze z Rygi, że minister Rebane przy okazji rocznicy obraził Łotwę, nosząc w dniu uroczystym jedynie order Polonia Restituta, nie zaś ostatnio nadany wysoki order łotewski. Wspomniany jest także fakt cytowania przez niego nieprzychylnej prasy niemieckiej. Ustęp o Niemczech umieszczony został na żadanie ministra Rebane pod wpływem polskim, stwierdza gazeta „Schlesische Zeitung”. Źródło: Archiwum Akt Nowych w Warszawie (dalej: AAN Warszawa), 4500 [Niemcy. Raporty] Konsulatu [RP We] Wrocławiu [O sytuacji gospodarczej i politycznej na Dolnym Śląsku i o sprawach polsko-niemieckich, wydawnictwa] Wydział Zachodni [(3N)] N.99, 1928 rok.

${ }^{14} \mathrm{~W}$ numerze $65 \mathrm{z} 8$. lutego 1928 roku.

${ }^{15}$ Heinrich Steiger był członkiem partii Centrum - pruskim ministrem rolnictwa.

${ }^{16}$ Volkswacht” w artykule „Polen und wir” z 20 grudnia 1927 roku, nr 297, podkreśla, mimo sceptycyzmu co do tempa sfinalizowania rokowań, dotychczasowo pomyślne rezultaty porozumień niemiecko-polskich.

${ }^{17}$ Został założony w roku 1918 początkowo jako związek o charakterze prywatnym. Działali w nim znani profesorowie Uniwersytetu Friedricha-Wilhelma i Technische Hochschule Breslau, a także przemysłowcy. Przewodniczącym został Adolf Weber. Instytut ten, początkowo zorientowany na pokojową współpracę z krajami na wschód od Niemiec, jest przykładem postępujących zmian programowych, wynikających z radykalizacji programu politycznego przez rząd III Rzeszy. Po roku 1933 badania udowadniają nieadekwatność polskich, ukraińskich czy litewskich badań kulturoznawczych. 
O negatywnym wpływie „Schlesische Volkszeitung” na relacje niemiecko-polskie pisał w roku 1928 w swym sprawozdaniu Józef Gluza, sekretarz konsulatu Poselstwa Polskiego w Berlinie. Według niego „Schlesische Volkszeitung” ma za zadanie paraliżować wszelkimi argumentami porozumienia polsko-niemieckie. Konsekwentnie podaje artykuły, których jedynym celem było obniżenie powagi Polski - wysuwały w tym celu przeważnie momenty religijne. Dla ilustracji kampanii prowadzonej przez dziennik załącza Gluza artykuł z 2 stycznia 1928 roku pt. Momentaufnahme aus dem neuen Polen, w którym autor twierdzi, że wybryki hakatyzmu pruskiego zostały stokrotnie powetowane przez polską politykę mniejszościową ${ }^{18}$.

Prasa śląska ukazuje się w tym czasie stosunkowo licznie. Jednym z jej najbardziej znanych organów jest „Breslauer Zeitung”" Jak raportują urzędnicy Poselstwa Polskiego w Berlinie gazeta ta przeważnie powtarza w formie telegramów wiadomości prasy stołecznej (berlińskiej) o stanie rokowań polsko-niemieckich i osiągniętych dotychczas rezultatach ${ }^{20}$.

${ }^{18}$ AAN, 4500. Konsulat RP we Wrocławiu. Raport prasowy nr 1 z 17 stycznia 1928 roku do MSZ - Wydział Prasowy PII.

${ }^{19}$ A oto przybliżony wykaz tytułów gazet, jakie wychodziły w przedwojennym Wrocławiu: „Acht-Uhr-Blatt” - założona w 1914 roku; „Allgemeine Oderzeitung” - 1846, gazeta katolicka; „Arbeiter Zeitung” - organ partii komunistycznej; „Breslauer Anzeiger” - 1845; „Breslauer Figaro” - 1830; „Breslauer Generalanzeiger” - 1888, jedna z największych pod względem nakładu gazeta na ziemiach wschodnich Niemiec. Od 1917 „Breslauer Neueste Nachrichten”, a od 1944 roku „Schlesischen Zeitung” i „Schlesischen Volkszeitung”; „Breslauer Hausblätter für das Volk”- 1863, a od 1869 roku „Schlesische Volkszeitung”, gazeta katolicka; „Breslauer Lokalblatt” - 1834; „Breslauer Morgenzeitung” - 1863 wydzielona z „Breslauer Anzeiger”; „Breslauer Neueste Nachrichten” - utworzona z „Breslauer Generalanzeiger”; „Breslauer Zeitung” - 1828, utworzona z „Neuen Breslauer Zeitung”; „Morgenzeitung” - 1853; „Neue Breslauer Zeitung” - 1820, zmieniła z czasem nazwę na „Breslauer Zeitung”; „Neue Oderzeitung” - utworzona z „Allgemeinen Oderzeitung”, gazeta katolicka; „Schlesisches Intelligenzblatt” - 1837; „Schlesisches Morgenblatt” - 1861; „Schlesischer Nouvellen - Courier” - 1659, najstarsza wrocławska gazeta (!); „Schlesische Tagespost” 1879, gazeta konserwatystów; „Schlesische Tageszeitung” - 1933, gazeta narodowych socjalistów; „Schlesische Volkszeitung” - 1869, gazeta katolicka; „Schlesische Zeitung”-1742; „Volkswacht” - gazeta socjaldemokratów; za: E.F. Franz, Bei uns in Breslau, Laumann Verlagsgesellschaft, Dülmen 1983. Wiele z tych tytułów zostało zdigitalizowanych i figuruje w zbiorach Śląskiej Biblioteki Cyfrowej.

${ }^{20}$ Jako charakterystyczny dla niemiecko-polskich relacji przytoczyć można następujący fakt: 31 grudnia 1927 roku ukazała się w „Breslauer Zeitung” nr 611 notatka Polnisches. Dziennik podaje w niej, że otrzymał z datą 27 grudnia 1927 roku pismo od prokuratora przy sądzie okręgowym w Tarnowskich Górach z żądaniem opublikowania bezpłatnie załączonego wyroku i nadesłania prokuratorowi jednego egzemplarza odnośnego numeru. W wyroku tym polski sąd zakazuje rozpowszechniania „Breslauer Zeitung” za artykuł z 9 grudnia 1927 roku pt. Rededuell Waldemars Zaleski, zawierający ustęp obraźliwy pod adresem Polski (mowa jest o rzekomo zagrabionych przez nasz kraj terenach). Jako gazeta nieprzyjazna Polsce wymieniany jest często w sprawozdaniach „Liegnitzer Tageblatt”, m.in. nr 288 z 9 grudnia 1927 roku i nr 289 z 10 grudnia 1927 roku z artykułem: Die Polonisierung im deutschen Osten (Polonizacja na niemieckim wschodzie). Oto fragment: „Polska niezadowolona z obszarów otrzymanych w wyniku dyktatu wersalskiego 
Podczas gdy prasa części Śląska należącej do Niemiec w relacjonowaniu spraw polskich, prawdopodobnie ze względu na specjalne położenie Śląska i bezpośrednie sąsiedztwo z Polską, zajmowała na ogół stanowisko umiarkowane ${ }^{21}$, to w sprawach ogólnej polityki zagranicznej i wewnętrznej jej publicystyka odzwierciedlała wiernie głos prasy z Berlina. Wspomniane wybory do Sejmu w Polsce w roku 1928 były omówione krytycznie, z narodowej perspektywy, w artykułach katolickiej „Schlesische Volkszeitung”22: Momentaufnahmen aus dem neuen Polen (Scenki z nowej Polski) i w „Volkswacht” - gazecie o profilu socjalistycznym: Korfanty lobt die preussische Regierung (Korfanty chwali pruski rząd) ${ }^{23}$. Konsul Bronisław Radowski z Konsulatu RP we Wrocławiu podsumowuje głosy prasy śląskiej w piśmie do MSZ (Wydział P II i P IV w Warszawie) z 27 lutego 1928 roku. Czytamy w nim:

Wybory w Polsce komentowane są przez prasę śląską. Pada pytanie: jakie są w wyborach szanse mniejszości niemieckiej? Ślązacy udowadniają swe rewelacje argumentami p. Korfantego, który stał się poniekąd powiernikiem opinii niemieckiej w stosunku do rządu i narodu polskiego ${ }^{24}$.

Relacje o tematyce polskiej są, mimo upływu lat, utrzymane w napastliwym i wrogim tonie. Jednym z głównych problemów we wzajemnych stosunkach jest sprawa Gdańska i polskiego dostępu do morza poprzez korytarz. Właśnie Alfred Wysocki z Poselstwa Polskiego w Berlinie często relacjonuje do MSZ Wydział P II w Warszawie o publicystyce na ten temat w czasopismach niemieckich. Według jednej z notatek, „Deutsche Rundschau” z 6 lipca 1932 roku pisze pod nagłówkiem Die polnische Gefahr (Polskie niebezpieczeństwo):

Zaostrzenie się stosunków francusko-niemieckich z powodu reparacji jest przyczyną podejmowania działań na wschodzie Rzeszy przez stronę francuską. Szczególnie

próbuje wszystkimi środkami w Prusach Wschodnich, na Pomorzu północno-wschodnim i na granicy Poznania i Prus Zachodnich stworzyć sobie bazę dla przyszłej inwazji. Jak wielkie jest niebezpieczeństwo, nikt sobie w Rzeszy nie uświadamia”. Źródło: ANN Warszawa 4500.

${ }^{21} \mathrm{Na}$ ogół nieprzychylnie wobec Polski pisała „Schlesische Zeitung”. Reprezentowała ona prawicowe skrzydło centrum i pozostawała zależna od nacjonalistycznych obszarników śląskich wyznania katolickiego.

${ }^{22} \mathrm{Nr} 2$ z 2 stycznia1928 roku.

${ }^{23} \mathrm{Nr} 32$ z 7 lutego 1928 roku.

${ }^{24}$ „Volkswacht” wspomina o rezolucji partii Korfantego w sejmie śląskim, protestującej przeciwko rzekomemu pogwałceniu zobowiązań ze strony rządu polskiego wynikających z autonomii śląskiej. ,Schlesische Zeitung”, „Schlesische Volkszeitung”, „,Breslauer Neueste Nachrichten” codziennie drukują sprawozdanie z akcji wyborczej oparte na wystąpieniach i atakach Korfantego przeciwko wojewodzie Grażyńskiemu i rządowi polskiemu w sprawie autonomii Śląska. Prasa niemiecka wyraźnie wyzyskuje propagandowo polemiczną aktywność polityczną Korfantego. Źródło: ANN Warszawa, 4500. 
dotyczy to Gdańska, gdzie wykorzystywana jest aktywność polska przeciw Rzeszy. Ujawnia się wpływ francuski na ,zimny pucz” w Kłajpedzie, ale także na sytuacje w Gdańsku. W trakcie swej mowy wygłoszonej w lutym 1932 r. wicewojewoda pomorski Seydlitz powoływał się na artykuły Żórawskiego w Kurjerze Warszawskim, w których to twierdził on, że militarne znaczenie Pomorza polega nie tylko na obronie połączeń z Gdynia i Gdańskiem, ale jednocześnie jest ono przeszkodą oddzielającą Prusy Wschodnie od Rzeszy i znacznie pomniejsza ich militarne znaczenie. Korytarz oznacza zatem wzmocnienie militarne Pomorza - liczy obecnie 1 milion mieszkańców. Z tego 15\% Niemców. Prowadzona na tym obszarze polska eksterminacyjna polityka agrarna i rewizja granic przy pomocy plebiscytu ma z każdym rokiem mniej szans powodzenia.

„Deutsche Rundschau” oskarża ponadto Polskę o próbę przeprowadzenia zamachu stanu w Gdańsku ${ }^{25}$.

W miesięczniku „Der Türmer”, relacjonuje dalej Wysocki, niejaki H. Reinhardt publikuje artykuł Zehn Jahregeteiltes Oberschlesien (Dziesięć lat podzielonego Górnego Śląska). Dziennikarz niemiecki, podkreślając ujemny bilans polskich rządów na Śląsku, uważa, że prowadzona jest polityka odniemczenia ziemi górnośląskiej. Autor twierdzi, że nawet ludność polska jest zdania, iż państwo polskie nie dało Śląskowi spodziewanych korzyści, szczególnie w wymiarze polityki gospodarczej. Nie ma zatem powodu do radosnego obchodzenia rocznicy ${ }^{26}$.

W czasopiśmie „Deutsche Grenzlande” politykę rzeczno-komunikacyjną Polski na Śląsku, według relacji Wysockiego, atakuje z kolei prof. dr Henning. W artykule Völkerrechtliche Reibungsflächen in der Grenzlandschiffahrt des Ostens (Punkty zapalne w międzynarodowym prawie dotyczacym granicznej żeglugi śródlądowej na Wschodzie) podkreśla, iż:

Na wschodzie panuje zamęt prawny w dziedzinie żeglugi rzecznej. Polska zdaniem autora nie wykorzystuje w pełni portu gdańskiego forsując w zamian rozwój Gdyni „zbudowanej na piasku”. W związku z tym Henning formułuje wniosek, iż oddanie Polsce całego biegu Wisły przez Traktat Wersalski doprowadziło do umyślnego zaniedbania nurtu Wisły. Polska zniszczyła pruską regulację Wisły, próbując wywrzeć presję gospodarczą na Gdańsk. To, iż Wisła płynie na obszarze granicznym między Gdańskiem, Niemcami a Polską powoduje możliwość rewizji traktatu wersalskiego i internacjonalizację Wisły ${ }^{27}$.

${ }^{25}$ AAN Warszawa, 4502. Ministerstwo Spraw Zagranicznych - Departament polityczno-ekonomiczny. Wydział Zachodni [(3N)] Niemcy. Raporty Poselstwa RP w Berlinie (O sytuacji politycznej, gospodarczej Niemiec i ich stosunkach z zagranicą, też z Polską, t. 2, 1932-1934).

${ }^{26}$ AAN Warszawa, 4502.

27 Tamże. 
W hanowerskim dwutygodniku „Ernte”, jak relacjonuje dalej Wysocki, F.L. Scholz-Giesecke w artykule zatytułowanym Schlagbereite Reservearmee-Schutz der Ostsee (Gotowa do uderzenia armia rezerwowa ochrona Battyku) twierdzi, iż Polska ma wobec Gdańska napastnicze zamiary, na co wskazuje tworzenie na Pomorzu w granicach VIII toruńskiego korpusu specjalnej armii rezerwowej, składającej się z organizacji przysposobienia wojskowego, związków gimnastycznych itd. ${ }^{28}$

$\mathrm{Z}$ czasem krytyka przybiera tylko na sile. W tomie Badania dotyczace historii Brandenburgii i Prus (1932) Johannes Papritz zamieszcza artykuł Französische Wissenschaftler zum Korridor problem (Francuscy naukowcy o problemie Korytarza $)^{29}$. Autor recenzuje w nim wydany w Paryżu zbiór odczytów wybitnych uczonych francuskich La Pologne et la Baltique. Według Papritza wszystkie artykuły są nierzetelne i stronnicze. Nauka francuska przyswoiła sobie w całości polskie tezy w sprawie korytarza i nie cofa się przed fałszowaniem tekstów historycznych.

W roku 1932 uwagę prasy, a w szczególności czasopisma „Der Auslanddeutsche", reprezentującego Towarzystwo Słowiańskie (Slavische Arbeitsgemeinschaft) przy Niemieckim Towarzystwie Studiów Wschodnioeuropejskich (Deutsche Gesellschaftzum Studium Osteuropas), przyciągnęła książka niemieckiego publicysty Maxa Hodanna Słowiański krag wokół Niemiec. Polska, Czechosłowacja i niemieckie problemy ze Wschodem ${ }^{30}$. Ta antypolska książka porusza istotne propagandowo zagadnienia tamtych lat. Tematem są stosunki polityczne, kulturalne i gospodarcze od czasów zaborów po współczesność. Polska, zdaniem Hodanna, utrudnia egzystencję ludności żydowskiej, prześladuje Białorusinów, ciemięży Ukraińców, nie dotrzymuje traktatów dotyczących mniejszości narodowych. Hodann krytycznie analizuje relacje polsko-francuskie oraz stosunek Polski do Czech z perspektywy niemieckiej. Gdańsk niszczony jest przez Polskę za pomocą Gdyni.

Wyczerpujące omówienie wspomnianych zagadnień wykracza poza ramy niniejszego opracowania, warto jednak przypomnieć raporty Alfreda Wysockie-

${ }^{28}$ Tamże.

${ }^{29}$ „Forschungen zur Brandenburgischen und Preußischen Geschichte” 1932, t. 44, z. 2. Tenże tygodnik w anonimowym artykule Von deutscher Schulnot in Kongresspolen (O niemieckim kryzysie szkolnym w Kongresówce) pisze o rzekomym zniszczeniu szkolnictwa niemieckiego na obszarze centralnej Polski - dziś nie ma tam już ani jednej szkoły czysto niemieckiego typu. W Łodzi, jak podaje tygodnik, rozbito organizację nauczycielską Deutscher Schulverein i zmuszono jej członków do wstąpienia do nowo założonej polskiej organizacji. Istniejące przy ewangelickich domach modlitwy szkoły niemieckie zamieniono na polskie. W niemieckich szkołach średnich wprowadzono tzw. dni polskie (bez języka niemieckiego). Artykuł porusza także problem stosunku rządu polskiego do szkolnictwa niemieckiego na Wołyniu. Kantorom niemieckim - pisano w publikacji - odbierano wielokrotnie prawa do nauczania. Za: AAN Warszawa, 4502.

${ }^{30}$ M. Hodann, Der sklavische Gürtel um Deutschland. Polen, die Tschechoslowakei und die deutschen Ostprobleme, Universitas - Deutsche Verlags-Aktiengesellschaft, Berlin 1932. 
go dotyczące sytuacji na polsko-niemieckim pograniczu. W Szczecinie, jak pisze w swych sprawozdaniach do MSZ, koła nacjonalistyczne założyły w roku 1932 organizację Deutscher Grenzkampfbund, która ma na celu organizowanie i wychowywanie na obszarze granicznym niemieckich sił chętnych do obrony i wzmacniania narodowej świadomości. Pozostaje ona w ścisłym w kontakcie z wschodnio-pruskim Heimatbund w Królewcu. Wspomina o tym, jak relacjonuje Wysocki, broszura niejakiego dra Zimmera z Olsztyna skierowana przeciwko żywiołowi polskiemu w Niemczech ${ }^{31}$. Zimmer atakuje rząd pruski za wydanie w grudniu 1928 roku dekretu w sprawie szkół mniejszości narodowościowych w Prusach Wschodnich, zarzucając, że dekret wytworzył podstawę dla polskiej „irredenty” w Prusach. Dopuszcza on też możliwość wspólnego regulowania języka szkolnego „w sensie wszechpolskim” dla Mazurów, Kaszubów i Górnoślązaków, przez co zaprzecza historycznej odrębności tych szczepów. Rząd pruski doprowadza do tego, że tak potrzebne „dialekty szczepowe” zostają w szkolnictwie pominięte na korzyść języka polskiego. Dekret o szkołach mniejszościowych spowodował, że wzdłuż granic korytarza powstały kulturalne i językowe grupy polskie, w praktyce stanowiące rozszerzenie polskiego frontu pomorskiego. Zimmer poświęca specjalną uwagę sprawie obwodu olsztyńskiego. Według niego jest to przedpole walki polsko-niemieckiej i dlatego musi być traktowane w sposób specjalny. Pruska polityka nie powinna polegać na Genewie jako gwarancie praw mniejszości narodowych, musi być wyraźnie antypolska. Polityka niemiecka winna budzić wrogie polskości siły na granicy wschodniej i przeprowadzić dzieło niszczenia państwa polskiego. Należy wykorzystać obojętność względem Polski niektórych szczepów - Litwinów, Mazurów czy Pomorzan. W broszurze Zimmera pobrzmiewa już wyraźnie ton nadchodzącego faszyzmu.

Hanowerski dwutygodnik „Ernte” publikuje w zeszycie 20/32 artykuł dr. Karla Brennerta Ein Freiheitskampf gegen polnische Willkür (Walka wolnościowa przeciwko polskiej samowoli) ${ }^{32}$, w którym autor na podstawie źródeł ukraińskich stara się sformułować szereg zarzutów na temat stosunków na ziemiach zamieszkałych przez ludność ukraińską. Lasy Wołynia i Polesia są terenem walk powstańczych zachodnio-ukraińskich chłopów przeciwko polskiej przemocy. Na obszarze szerokości około stu kilometrów pomiędzy Brześciem nad Bugiem a granicą niemiecką wzdłuż Prypeci i jej dopływów chłopi zachodnio-ukraińscy prowadzą walkę podjazdowa przeciwko Polsce. Według Brennerta oddziały wojska polskiego - głównie 50. pułk piechoty w znacznej części złożony z ukraińskich żołnierzy - zostały zastąpione przez oddziały kawaleryjskie Korpusu Ochrony Pogranicza i policję z województwa warszawskiego i lubelskiego. Walka nie ustaje, ponieważ powstańcy ukraińscy są zaopatrzeni w broń, amunicję

\footnotetext{
${ }^{31}$ N. Zimmer, Kampf um Ostpreußen, Hrsg. von deutschen Grenzlandbund, Stettin 1932.

32 Alfred Wysocki relacjonuje do MSZ 8 grudnia 1932 roku. Źródło: AAN Warszawa, 4502.
} 
i żywność. Rząd polski, nie będąc w stanie stłumić powstania, mści się na bezbronnej ludności. Stosuje terror, rozwiązuje organizacje polityczne, kulturalne, przeprowadza masowe areszty, prześladuje prasę. Jako powód powstania chłopów określanych jako zachodnio-pruscy Brennert podaje ucisk narodowy, nacisk podatkowy, ruinę gospodarczą w wyniku polonizacyjnej polityki Polski.

Miesięcznik „Volkund Reich” ${ }^{33}$ w numerze 11/32 omawia artykuł Hansa Gerta von Esebecka, naczelnego redaktora „Allensteiner Zeitung”, pt. Das Ergebnis der preußischen Minderheitenpolitik (Wynik pruskiej polityki wobec mniejszości narodowych). Jest on poświęcony dotychczasowej polityce rządu pruskiego względem mniejszości narodowych, zwłaszcza stosowaniu ustawy o szkołach mniejszościowych wobec ludności polskiej w Prusach. Esebeck powołuje się na artykuł dr. Rathenaua w zeszycie lipcowym (1932) - Volkund Reich [Naród i Rzesza]. Liberalna polityka rządu pruskiego wobec mniejszości polskiej skończyła się fiaskiem. Przy zakładaniu nowych szkół należy wysłuchać opinii lokalnych władz politycznych. Nauczycielom Polakom - obywatelom polskim przyjazd do Niemiec powinien być dozwolony dopiero po założeniu nowej szkoły. Sprawa szkolnictwa mniejszościowego powinna być uregulowana na podstawie prawodawstwa Rzeszy - to umożliwi działanie w Lidze Narodów w tej sprawie i w sprawie mniejszości narodowej niemieckiej w Polsce. Pruska ustawa o szkolnictwie mniejszościowym powinna być, zdaniem Esebecka, anulowana.

Propagandowy nacisk prasy pruskiej skierowany jest przeciwko Polsce określanej mianem państwa sezonowego i uderza bezpośrednio w narodową mniejszość polską w Niemczech, reprezentowaną przez prasę polską. W okresie republiki weimarskiej posiadała ona jeszcze uprawnienia przysługujące mniejszościom narodowym.

Prasa polska działała w republice weimarskiej właśnie jako prasa polskiej mniejszości narodowej ${ }^{34}$. Broniła na ogół wiernie interesów głównej organizacji polonijnej, jaką był Związek Polaków w Niemczech, pełniący wówczas funkcję zrzeszenia politycznego Polaków - działalność prowadził w 370 miejscowoś$\operatorname{ciach}^{35}$. Oprócz niego istniały: Polsko-Katolickie Towarzystwo Szkolne w Opo-

\footnotetext{
33 „Volk und Reich” 1932, nr 11/32. Źródło: AAN Warszawa, 4502.

${ }^{34}$ Polacy w Niemczech należeli do Związku Narodowych Mniejszości (Verband der nationalen Minderheiten Deutschlands) - jako Bund der Polen in Deutschland.

${ }^{35}$ Pismo Konsulatu Generalnego Rzeczpospolitej w Opolu z 8 lutego 1936 roku do wojewody śląskiego w Katowicach. Konsul Bohdan Samborski w piśmie zatytułowanym Referat o położeniu ludności polskiej na Śląsku Opolskim pisze, iż biuro Związku Polaków w Opolu załatwia sprawy wpływające od mężów zaufania i innych organizacji polskich. Organizuje biblioteki, świetlice, kursy, imprezy kulturalne, akcję teatralną i sportową. Występy teatralne - w 1934/1935 roku to aż 23 imprezy, w tym występy teatru katowickiego - około 15 imprez dla w sumie 8,5 tys. osób. 74 wykładów Uniwersytetu Ludowego wysłuchało w roku 1934/1935 w 22 miejscowościach 7 tys. słuchaczy. W wycieczkach i pielgrzymkach do Polski uczestniczyło 11762 osoby. Związek Polaków w Niemczech utrzymuje Domy Polskie w Opolu, Bytomiu, Gliwicach, Strzelcach, Zabrzu i Raciborzu.
} 
lu zajmujące się prywatną oświatą szkolną i pozaszkolną, Związek Towarzystw Młodzieży w Opolu, Związek Kół Śpiewaczych z siedzibą w Zabrzu, Górnośląskie Zjednoczenie Rolników z siedzibą w Opolu oraz Związki Zawodowe. Wśród organizacji polskich $w$ Niemczech wspomnieć należy także o nastawionym antyrządowo Związku Wzajemnej Pomocy z siedzibą w Wanne-Eickel ${ }^{36}$.

Prasa polska skupiała się w kilku ośrodkach, były to: Śląsk Opolski i Opole, gdzie wydawano „Nowiny Codzienne”, „Głos Pogranicza i Kaszub”, „Dziennik Raciborski”, „Głos Ludu” (organ PPS na Śląsku Opolskim wydawany w Katowicach) czy „Katolika Trzyrazowego” (pod wpływem ideologii i działalności Korfantego); Nadrenia Westfalia, Herne - „Dziennik Berliński”, „Naród”, „Polak w Niemczech”, „Młody Polak w Niemczech”, „Mały Polak w Niemczech” oraz Warmia i Mazury, Olsztyn - „Gazeta Olsztyńska”, „Mazur”, „Głos Ewangelijny”. Wśród Mazurów rozwinął się także samodzielny ruch wokół drukowanego w Berlinie wydawnictwa „Cech” - „Głos Polski z Berlina” ${ }^{37}$.

Po dojściu nazistów do władzy sytuacja Polaków w Rzeszy, ale także na Warmii Śląsku i Mazurach pogarsza się ${ }^{38}$.

${ }^{36}$ AAN Warszawa, 4778, 4779.

${ }^{37}$ Fragment notatki przygotowanej przez dr. Langroda dla ambasadora Lipskiego pt. Sprawa polska w Niemczech - tezy polityczne i praktyczne, w której omawia on sprawę działalności kulturalnej i politycznej mniejszości polskiej w Niemczech. Została ona opracowana w Poselstwie w Berlinie. Langrod pisze m.in., iż „Niemcy przywiązują ogromną wagę do sprawy polskiej i poświęcają temu zagadnieniu na pozór niewspółmiernie wielką ilość czasu, środków finansowych i wysiłków w wielu dziedzinach. Dla Niemców cały kraj po Łabę jest polem walki polsko-niemieckiej [...]". Omawiając życie organizacyjne Polaków w Niemczech, Langrod wspomina, że Polonia wydaje pięć dzienników - są to: „Dziennik Berliński” w Berlinie, „Nowiny Codzienne” w Opolu, „Głos Pogranicza i Kaszub” w Opolu, „Naród” w Herne, „Gazeta Olsztyńska” w Olsztynie, a następnie dyplomata omawia dane poszczególnych czasopism.

${ }^{38}$ Tezę tę potwierdza raport dyplomatyczny dotyczący Śląska. Konsul Rzeczypospolitej Polskiej w Opolu Samborski ocenia, iż działania przeciwko mniejszości polskiej w Niemczech przybrały znacznie na sile od chwili przejęcia władzy przez Hitlera. Ludność polska jest jego zdaniem przedmiotem zaciekłej akcji germanizacyjnej ,,prowadzonej w ukryciu i przy zachowaniu koniecznych pozorów". Nowe formy ustrojowe Niemiec jako państwa totalnego dają tego rodzaju dążeniom „prawie nieograniczone możliwości ekspansji”. Śląsk uważany jest przez Niemców, pisze Samborski, za jedną z baz wypadowych na wschód - BollwerkOberschlesien. Wspomina szereg ustaw ograniczających dotychczasowe swobody obywatelskie, świadome działanie władz i organów partyjnych i usunięcie Polaków od udziału w życiu politycznym. Są to jego zdaniem takie posunięcia jak: ograniczenie własności rolnej przez wprowadzenie zagród dziedzicznych, utrudnienia dewizowe, likwidacja związków zawodowych, akcja oddłużeniowa przeciw bankom polskim, przymus służby wojskowej i służby pracy, przymusowe zabiegi sterylizacyjne. Każde z tych posunięć zmusza Polaków do pogłębienia integracji ze społeczeństwem niemieckim. Wpływy ideologiczne partii ujawniają się szczególnie silnie w szkole, opiece społecznej, kościele, miejscu pracy. Prowadzi się także pseudonaukową propagandę na rzecz niemieckości Śląska Opolskiego. „Wypadków jawnego terroru jest stosunkowo niewiele [...] daleko niebezpieczniejsze są [...] zewnętrznie poprawne akty antypolskie". Ludność polska może bronić się przed akcją germanizacyjną, odwołując się do postanowień Konwencji Genewskiej - przewidziano w jej ustawach 
Konsulat Rzeczypospolitej w Olsztynie uskarża się nader często na działalność władz niemieckich ${ }^{39}$. Dnia 2 marca 1936 roku raportuje do Ambasady Polskiej w Berlinie w sprawie walki z polskością, donosząc, iż Regencja Olsztyńska odmówiła zezwolenia na uruchomienie kursów języka polskiego. W drukarni „Gazety Olsztyńskiej” władze niemieckie skonfiskowały „Kalendarz Mariański”, dodawany od szeregu lat do pisma na Nowy Rok ${ }^{40}$.

Na podstawie raportów konsulatów można wnioskować, że akcja przeciw mniejszości polskiej dała się odczuć szczególnie na terenie Warmii. Referent Tadeusz Kunicki w notatce skierowanej do Wiktora Drymmera, dyrektora Departamentu Konsularnego MSZ w Warszawie ${ }^{41}$, pisze, że trwa akcja zmierzająca do zlikwidowania prasy polskiej przez stopniowe eliminowanie poszczególnych pracodawców polskich z grona osób uprawnionych według ustawy prasowej do podpisywania wydawnictw polskich. Zawieszono w prawach wykonywania zawodu m.in. redaktora „Katolika” Pawletta oraz redaktora „Gazety Olsztyńskiej” - Jankowskiego. „Katolika” podpisuje, jak pisze Kunicki, „pan Łangowski redaktor «Nowin Codziennych», a «Gazetę Olsztyńską»p. Seweryn Pieniężny»"42.

Konsulat RP w Olsztynie raportuje pismem z 18 marca 1936 roku do ambasadora RP w Berlinie w sprawie położenia ludności polskiej w Prusach Wschodnich, pisząc o aktywności NSDAP, iż początkowo po pakcie o nieagresji z 26 stycznia 1934 roku zaznaczyła się poprawa sytuacji po zwolnieniu starych urzędników weimarskich i zastąpieniu ich członkami NSDAP. Ich niesprawności urzędowej zawdzięczali Polacy możność skonsolidowania szeregów i wzmożenia pracy or-

możność wnoszenia skarg do Komisji Mieszanej w niemieckim Urzędzie do Spraw Mniejszości (w 1936 roku - 87 skarg), do Trybunału Rozjemczego i Polskiego Komisarza do spraw pracy oraz organizacji narodowo-kulturalnych. Z procedury mniejszościowej w Komisji Mieszanej ludność polska może korzystać za pośrednictwem Związku Polaków. Zródło: Pismo Konsulatu Generalnego Rzeczpospolitej w Opolu z dn. 8.02.1936 r. do wojewody śląskiego w Katowicach pt. Referat o położeniu ludności polskiej na Śląsku Opolskim. AAN, Warszawa, 4778.

${ }^{39}$ Ambasada w Berlinie, z którą Konsulat w Olsztynie utrzymuje stałą korespondencję, podkreśla w jednym z raportów skierowanych do wydziału politycznego MSZ, iż zaostrza się kurs wobec prasy polskiej w Niemczech - ostatnio w stosunku do pism młodzieżowych. Jako polityczne dotychczas traktowano pisma codzienne, a teraz także pozostałe periodyki - w tym pisma młodzieżowe. Landesverband Berlin im Reichsverband der deutschen Presse pisze w piśmie z 14 lutego 1936 roku do Związku Polaków w Niemczech: „Es handelt sich bei Ihren Zeitschriften um solche des erzieherischen und minderheitskulturellen Charakters. Zeitschriften solchen Charakters sind aber nach dem Schriftleitergesetz als politisch anzusehen” („W wypadku waszych czasopism chodzi głównie o pielęgnowanie kultury mniejszości narodowych i publikacje o charakterze wychowawczym. Czasopisma takie mają jednak według ustawy Schriftleitergesetz charakter polityczny" [tłumaczenie własne]).

${ }^{40}$ AAN Warszawa, 4779.

${ }^{41}$ Tamże. MSZ, Wydział Polityczny II - notatka w sprawie położenia mniejszości polskiej w Niemczech w styczniu i w lutym 1936 roku.

42 „Dziennik Berliński” publikuje 7 marca 1936 roku artykuł pt. Redaktorowi Kulturwehr p. J. Skali zakazano wykonywania zawodu dziennikarskiego. 
ganizacyjnej (m.in. stworzenie harcerstwa oraz Towarzystwa Mowy i Obyczaju Polskiego). Jednak sytuacja zmieniła się na niekorzyść:

Instytucja zagrody dziedzicznej, organizacje zawodowe, zbytu produktów rolnych, pomocy zimowej, wsparć dla wielodzietnych rodzin, podporządkowanie całości jednolitemu kierownictwu partii, wszystko to dało Niemcom nieznane dotychczas możliwości nacisku na poszczególne jednostki. Zaczęto zwracać także uwagę na ruch polski. ${ }^{43}$

Wymienione zostają w raporcie liczne utrudnienia oświatowe i religijne. Są to m.in.:

Wstrzymanie budowy gimnazjum w Kwidzynie, odmowa zezwolenia na przeróbkę lokalu dla szkoły polskiej, [...] nacisk na rodziców posyłających dzieci do szkół polskich, pozbawienia prawa nauczania trzech nauczycieli [...], odmowa przyznania prawa nauczania wychowankom seminarium w Rogóźnie i Lesznie, procesy karne 4 nauczycieli [...], zawieszenie redaktora „Gazety Olsztyńskiej”, niszczenie kolportażu „Mazura”, uwięzienie redaktora odpowiedzialnego tego pisma Siarkowskiego, konfiskata „Kalendarza dla Mazurów” i „Kalendarza Marijańskiego”, zakaz kolportażu «Krzyżaków» H. Sienkiewicza, niedopuszczenie do praktyki zawodowej wychowanków szkół polskich, odmowa zezwolenia na otwarcie filii Banku Ludowego w Szczytnie przez cały tydzień, [...] zwolnienia z pracy osób przyznających się do polskości $[\ldots]$.

$\mathrm{Z}$ czasem sytuacja jedynie się pogarsza. Kierownik konsulatu - wicekonsul Antoni Zalewski coraz częściej narzeka w swych raportach na brak skonsolidowanych działań wśród Polonii i aktywność osób spoza organizacji. Sprawę utrudnia ideologiczne stanowisko narodowych socjalistów, traktujących zagadnienie współegzystencji mniejszości narodowych jako niebyłe. Brak uznania praw tych mniejszości doprowadzi z czasem do ich podporzadkowania i ciemiężenia.

Republika weimarska wydaje się być na drodze do stania się, w sensie medialnym, ideokracją. Wraz z upływem lat coraz bardziej widać, iż myśl narodowa podzielana jest zgodnie przez niemal wszystkie partie polityczne i ich organy prasowe. Stosunek do państwa polskiego jest tego przykładem.

Prowadzone w latach czterdziestych przez badaczy amerykańskich próby określenia realnego wpływu mediów masowych na zmiany postaw u odbiorców zaowocowały zbudowaniem poglądu, iż „komunikowanie masowe nie jest zwykle wystarczającą ani konieczną przyczyną wpływu, ale zazwyczaj działa przez

${ }^{43}$ AAN, Warszawa, 4780.: Niemcy. Ośrodki Polskie (położenie Polaków i działalność władz. Raporty placówek polskich w Niemczech, korespondencja, wycinki prasowe), Tom II - 1932-1936. 
splot czynników pośredniczących"44. Rozumiano przez nie kompozycję stosunków społecznych i wydawały się one ważniejsze od mediów ${ }^{45}$. Teza o ograniczonym wpływie mediów z czasem ustąpiła przekonaniu, że środki masowego przekazu posiadają istotne znaczenie. Omówiona w artykule debata polityczna w prasie wskazuje na niemalże jednolity front ideowy wobec Polski. Można zatem wnioskować, że środowisko polityczne w Niemczech, zwłaszcza w latach trzydziestych dwudziestego wieku, używało mediów do kreacji politycznej na szeroką skalę.

Media - głównie prasa - zaczynały być uznawane przez rządzące partie polityczne za posiadające aktywną zdolność kształtowania masowej opinii, jak również za narzędzie wpływające na zmianę obyczajów oraz zachowania wedle założeń tych, którzy mieli nad mediami władzę i sprawowali nad nimi funkcję kontrolną. Funkcjonowały w ramach społeczeństw, które umożliwiały im swobodny i duży rozwój, co można obserwować na przykładzie republiki weimarskiej.

\section{Bibliografia}

Archiwum Akt Nowych w Warszawie, 4500: [Niemcy. Raporty] Konsulatu [RP We] Wrocławiu [O sytuacji gospodarczej i politycznej na Dolnym Śląsku i o sprawach polsko-niemieckich, wydawnictwa,] Wydział Zachodni [(3N)] N. 99, 1928 rok.

Archiwum Akt Nowych w Warszawie, 4502: Ministerstwo Spraw Zagranicznych - Departament polityczno-ekonomiczny. Wydział Zachodni [(3N)] Niemcy. Raporty Poselstwa RP w Berlinie: O sytuacji politycznej, gospodarczej Niemiec i ich stosunkach z zagranicą, też z Polską, t. 2, 1932-1934.

Archiwum Akt Nowych w Warszawie, 4778: Niemcy. Ośrodki polskie - położenie Polaków w Niemczech. Memoriały (1933).

Archiwum Akt Nowych w Warszawie, 4779: Niemcy. Ośrodki polskie (położenie Polaków - działalność organizacji polskich w Niemczech, antypolska działalność władz. Raporty placówek polskich w Niemczech, korespondencja, wycinki prasowe), t. 1, 1935-1936.

Arendt H., Korzenie totalitaryzmu, Wydawnictwo Akademickie i Profesjonalne, Warszawa 2008.

Bała P., Wielomski A., Carl Schmitt a Konstytucja Rzeczpospolitej polskiej. Studium przypadku ratyfikacji Traktatu Lizbońskiego - rola prezydenta RP, Klub Zachowawczo-Monarchistyczny, Warszawa 2008.

Becker M., Ideologiegeleitete Dikaturen in Deutschland, Forum Junge Politikwissenschaft, Band 18, BouvierVerlag, Bonn 2009.

Friedrich C., Brzeziński Z., Totalitarianism dictatorship and autocracy, Harvard University Press, Cambridge 1956.

Goban-Klas T., Media i komunikowanie masowe, Wydawnictwo Naukowe PWN, Warszawa 2009. Kielmansegg P., Die Grammatik der Freiheit. Acht Versuche über den demokratischen Verfassungsstaat, Nomos Verlagsgesellschaft, Baden-Baden 2013.

${ }^{44}$ T. Goban-Klas, Media i komunikowanie masowe, Wydawnictwo Naukowe PWN, Warszawa 2009, s. 244.

45 Tamże. 
Linz J., Totalitäre und autoritäre Regime, Potsdamer Textbücher, Bd 4, WeltTrends e.V., Potsdam 2009.

Neumann F., Demokratischer und Autoritärer Staat. Studien zur politischen Theorie, Frankfurt am Main 1967.

Seymour-Ure C., The political Impact of Mass Media, Constable, London 1974.

Weber M., Gospodarka i społeczeństwo. Zarys socjologii rozumiejącej, Wydawnictwo Naukowe PWN, Warszawa 2002.

\author{
Marek Ostrowski
}

\title{
On the road to dictatorship. Politics and Propaganda of the Weimar Republic in the Polish and German Press to 1933
}

\section{(Summary)}

The article discusses the Polish-German relations in the press during the Weimar Republic. Keywords: the Weimar Republic, the press, the Polish-German relations. 